\title{
Berou en bekering in die prediking van die profete: geïterpreteer binne die raamwerk van die verbond
}

\author{
A.W. Coetzee \\ Departement Klassieke \& Semitistiek \\ Potchefstroomse Universiteit vir CHO \\ POTCHEFSTROOM
}

\begin{abstract}
Repentance and conversion in the message of the prophets: interpreted within the covenant

In this article the idea of repentance and conversion as preached by the prophets is discussed within the framework of the covenant. Repentance and conversion are located within the covenant by indicating that it is the logical step after the breaking of the covenant by the people (Deut. 29 and 30). The way in which repentance and conversion are understood in the Prophets is then discussed in more detail, and the following aspects are argued: (i) the call to conversion is directed primarily towards Israel; (ii) conversion implies a turning away from sin and a turning back towards God. Finally it is indicated that the prophets understood conversion as having been initiated by God, although man also had a responsibility in this process.
\end{abstract}

\section{Inleiding}

\subsection{Probleemstelling}

Die profete se prediking is deur die eeue sedert hulle optrede op baie verskillende maniere geïnterpreteer (Le Roux, 1986:155-157). ${ }^{1}$ Die rede hiervoor is waarskynlik omdat so baie aspekte in die boodskap van die Profeteboeke moeilik verstaanbaar is en dat daar soveel gegewens is wat op die oog af teenstrydig is met mekaar. Helberg (1980:174) getuig ook van hierdie moeilike aard van die profetiese boeke deur hulle 'paradoksale karakter' soos volg te

1 Vergelyk verai Copeland (1984) wat 'n oorsig bied oor die uiteenlopende moderne standpunte oor die Profete-boeke. 
omskryf: "Enersyds verkondig die profete 'n ontsettende en onontvlugbare oordeel, andersyds 'n wonderlike verlossing. Dit is soos twee ewewydige lyne wat langs mekaar loop en nie wil ontmoet nie."

Dit is hierdie paradoks in die profetiese boodskap wat verantwoordelik was vir die meeste van die interpretasieprobleme met betrekking tot die Profete-boeke. Dit is ook veral hierdie boodskap wat deur die Israeliete verkeerd geïnterpreteer is en wat tot gevolg gehad het dat hulle die profete nie reg verstaan het nie. Hulle kon nie die twee pole van oordeel en verlossing met mekaar versoen nie. Vir hulle was dit nie 'n paradoks ('n oënskynlike teenstelling) nie, maar 'n werklike teenstrydigheid; gevolglik het hulle net die verlossingselement raakgesien. Hulle kon dit nie logies uitredeneer dat Jahweh wat hulle as sy volk uitgekies het, hulle ook kan straf nie en daarom het hulle die oordeelswoord van die profete verwerp en dit nie geglo nie, dit nie verstaan nie (vgl. Helberg, 1992:246).

In hierdie artikel word hierdie probleem bespreek. Hier word in die algemeen gepoog om die profetiese boodskap beter te verstaan, en in die besonder om 'n oplossing te vind vir hierdie paradoks: wat is die verband tussen die oordeel en verlossing in die profete se prediking?

\subsection{Uitgangspunt}

\subsubsection{Die verbond as sentrale openbaringslyn}

Een van die grondbeginsels van gereformeerde Bybelinterpretasie is dat die dele in die lig van die geheel verstaan moet word (Coetzee, et al., 1980:23-24.), dit wil sê die sentrale openbaringsboodskap van die Skrif moet as riglyn gebruik word by die interpretasie van kleiner geïsoleerde gedeeltes. Dit is egter geensins 'n maklike taak nie - veral met betrekking tot die Ou Testament. Om die beginsel te kan toepas moet die sentrale openbaringsboodskap van die $\mathrm{Ou}$ Testament eers bepaal word, en daar bestaan groot verskille tussen teoloë oor wat hierdie sentrum is. ${ }^{2}$ Boonop bestaan die gevaar dat die openbaring verskraal kan word as dit binne net een sentrale boodskap gelees word, terwyl dit in der waarheid ryk en gevarieerd is. Die eis tot interpretasie binne 'n sentrale tema en tot erkenning van die gevarieerdheid van die openbaring is dus in konflik met mekaar. Hier word voorgestel dat die probleem opgelos kan word deur nie dié sentrale tema te soek nie, maar eerder te erken dat daar verskeie breë openbaringslyne in die Ou Testament is (vgl. Lion-Cachet, 1989:5 en Helberg, 1993:45-46). Die betekenis van die Ou-Testamentiese openbaring

2 Vergelyk Hasel (1991:139 e.v.) wat 'n oorsig gee oor verskillende standpunte insake hierdie saak. 
word dan nie verkry deur die Ou Testament binne net een sentrale tema te interpreteer nie, maar deur dit te interpreteer binne verskeie van hierdie sentrale openbaringslyne.

In hierdie artikel word voorgehou dat die verbondsgedagte een van die sentrale openbaringslyne in die Ou Testament is en die prediking van die profete met betrekking tot berou en bekering word binne hierdie raamwerk bespreek. In die beredenering van hierdie aspek word nie voorgehou dat die volle profetiese boodskap in sy geheel op hierdie wyse ontsluit kan word nie, aangesien dit maar een van die lyne is wat deur die Profete-boeke loop. Sekere aspekte van die prediking van die profete kan wel so beter verstaan word. Die artikel is dus 'n poging om 'n bydrae te maak tot die verstaan van die Profete en nie om die Profete volledig uit te lê nie.

Oor die legitimiteit van die verbond as 'n sentrale gedagte in die Ou Testament is daar baie dispuut. Hierdie dispuut het in die vorige eeu reeds begin met Wellhausen wat die verbond as 'n laat ontwikkeling in die Israelitiese godsdiens beskou het (vgl. byvoorbeeld Wellhausen, 1885:442-443). Volgens Wellhausen het die verbondsgedagte eers in die agtste eeu voor Christus ontwikkel sodat verwysings daarna in ouer boeke van die Bybel nie outentieke verwysings is nie, maar latere byvoegings. Hierdie standpunt geniet vandag steeds aanhang by prominente teoloë, waaronder Nicholson (1986:191-193). As hierdie standpunt aanvaar word, is dit baie problematies om die verbond as 'n sentrale lyn in die Ou Testament te aanvaar. In hierdie artikel word egter aangesluit by teoloë soos Bright (1976:40-42) en Helberg (1990:81 e.v.) wat die verbond as 'n veel ouer tradisie beskou. Verder word die teks van die Bybel aanvaar en geïnterpreteer soos wat dit vandag daar uitsien. Selfs al sou daar dus latere redaksionele byvoegings van verbondsgedeeltes wees, word die teks as Godsopenbaring aanvaar soos wat dit is. Die verbondsidee sou dus selfs dan ook 'n legitieme deel van die teks wees wat in interpretasie in ag geneem moet word.

Binne hierdie verbondsraamwerk word in hierdie artikel aangetoon dat die teenstelling tussen oordeel en verlossing in die profetiese prediking opgelos word as dit binne die verbondsraamwerk gelees word. Die verbond het bepaal dat God die volk sou straf as hulle nie die verbondsbepalings gehoorsaam nie. Die verbond het egter ook bepaal dat die volk weer geseën sal word as hulle berou het oor hulle sonde en hulle bekeer. Binne die verbond slaan berou en bekering dus 'n brug tussen oordeel en verlossing. Verder word ook aangetoon hoedat die profete se prediking oor berou en bekering beter verstaan word as dit binne 'n verbondsraamwerk gelees word. 


\subsubsection{Die profetiese boodskap?}

In hierdie artikel word deurgaans van die profetiese boodskap gepraat asof dit eenduidig is en asof die verskillende profete almal presies dieselfde gesê het. Dit is natuurlik nie so eenvoudig nie (vgl. byvoorbeeld 2 . hier onder waar verwys word na die verskil tussen die voor- en na-eksiliese profete). Hierdie artikel is egter bedoel om 'n breë raamwerk te gee waarbinne die individuele profete dan geïnterpreteer kan word met inagneming van elk se besondere beklemtoning. In hierdie artikel word gestel dat al die profete oor berou en bekering preek en dat almal basies dieselfde sê - almal gee immers openbaring van een en dieselfde onveranderbare God. Elkeen het egter sy eie styl en eie beklemtoning na gelang van sy besondere omstandighede. Amos (wat voor die ballingskap optree) konsentreer byvoorbeeld op die onafwendbaarheid van die oordeel en die ernstige oproep tot bekering. Esegiël (wat in die ballingskap optree) lê minder klem op die oordeel (dit het immers reeds aangebreek) - hy lê eerder klem op die onafwendbare verlossing wat volg op die bekering. Tog kan albei se prediking geplaas word êrens binne die raamwerk wat in hierdie artikel daargestel is. Hierdie artikel moet gesien word as 'n moontlike sleutel waarmee individuele profete se prediking ontsluit kan word, en nie as die ontsluiting self nie.

\subsection{Opset}

Hierdie artikel word in die volgende hoofdele aangebied:

* Die profetiese paradoks: Die paradoks tussen oordeel en verlossing word verduidelik ten einde die problematiese in die interpretasie van die Profeteboeke aan die orde te stel.

* Die verbond: Daardie aspekte van die verbond wat belangrik is vir die verstaan van die profetiese prediking met betrekking tot berou en bekering word bespreek. Dit dien ook as oplossing vir die profetiese paradoks.

* Berou en bekering in die Profete-boeke: Hier word bespreek hoe berou en bekering in die profetiese prediking figureer en daar word aangetoon hoedat die verbondsraamwerk kan help om probleme op te los.

\section{Die profetiese paradoks: oordeel en verlossing}

Oordeel en verlossing is wel bekend as twee van die vernaamste elemente van die profetiese prediking. ${ }^{3}$ Dit is dus nie nodig om dit in diepte te bespreek nie.

3 Vergelyk byvoorbeeld Zimmerli (1977:183 e.v.) en Westermann (1982:118 e.v.) wat albei die profetiese boodskap in hierdie tweedeling van oordeel en verlossing bespreek. 
Daar word eerder aangedui hoedat hierdie twee elemente in die profetiese prediking as paradoks funksioneer en as teenstelling geïnterpreteer kan word.

Die profete verkondig enersyds die onafwendbare oordeel van God. Hierdie tipe prediking word veral aangetref by voor-eksiliese profete (Westermann, 1982:141). As voorbeeld kan na Amos 5:19 verwys word. Volgens hierdie Skrifgedeelte is daar geen sin vir die volk om nog te probeer om die oordeel te ontvlug nie. Dit sal wees soos iemand wat ontvlug van 'n leeu, maar deur'n beer verskeur word. Daar is geen uitkoms meer nie - die volk het gesondig sonder berou en die oordeel is noodwendig. Andersyds verkondig die profete ook die onstuitbare verlossing van God. In hierdie opsig weer is dit veral die eksiliese en na-eksiliese profete wat ter sprake kom (Westermann, 1982:141). Haggai 2:18 en verder kan as voorbeeld dien. Dit is die verlossing en seën wat uiteindelik triomfeer - dit is daarmee wat die profesie eindig. Die voorafgaande oordeel (vgl. byvoorbeeld Haggai 1:6, 9-11) kon die verlossing nie negeer nie.

Dit is reeds duidelik dat hierdie twee elemente van die profetiese boodskap met mekaar in kontras is. Die spanning word verder verhoog deurdat die oordeelsen verlossingsprediking nie geïsoleer van mekaar voorkom nie. Alhoewel oordeel by die voor-eksiliese profete oorheers, kom verlossingsprediking tog ook voor. Amos het onafwendbare oordeel aangekondig; tog het hy ook oordeel verkondig wat wel afgeweer is. By die eerste twee van sy vyf visioene (Amos 7 en 8 ), het hy met sukses ingetree vir die volk en die oordeel is afgewend. Net so was verlossing nie al wat die na-eksiliese profete gepreek het nie. Ten spyte daarvan dat Haggai die verlossing as noodwendig gesien het (vgl. hierbo), het hy ook oordeel verkondig (vgl. Haggai 1:6, 9-11).

Hierdie twee teenstellende pole van die profetiese prediking het vir Israel 'n krisis veroorsaak. God se uitverkiesing, bystand en seën het vir Israel hulle bestaan gelegitimeer (Le Roux, 1986:127). Die aankondigings van seën en verlossing was dus in ooreenstemming met die volk se godsdienstige beskouings en het dit bevestig. Die oordeelsaankondigings het hulle egter totaal ontnugter. Wat Le Roux (1986:152) sê oor Amos se oordeelsaankondigings geld ook vir dié van die ander profete: "Amos se woorde het die bestaansgrond van sowel die staat as die godsdiens aangetas ...". Die onafwendbare oordeel wat die profete verkondig het, het dus die volk in 'n eksistensiële krisis gedompel. Hulle het in groot vertwyfeling verval: as die seën en ondersteuning van God vervang word deur straf en oordeel, watter gronde het hulle dan nog om as (Gods)volk te bestaan? Eksistensiële angs soos hierdie kan nie deur die mens genegeer word nie en moet op een of ander manier gehanteer word. Die volk moes of hulle siening van hulle bestaansgrond aanpas om in ooreenstemming te kom met die volle verbond, of hulle 
moes die oordeelsprediking verwerp. Hulle het die tweede opsie gekies en in der waarheid die oordeelsprediking geïgnoreer, of in elk geval gemaak of dit nie op hulle van toepassing is nie. Hulle het dus voortgeleef in 'n valse gerustheid. Vergelyk byvoorbeeld Amos 5:18 wat dui op die volk se valse gerustheid. Vergelyk ook hulle vraag in Maleagi 3:7: "Waarin moet ons terugkeer?" (1933-vertaling.) Hierdie vraag is nie 'n opregte vraag waarin raad gevra word oor hoe hulle hulleself moet bekeer nie. "The question is not bona fide, but a virtual declaration of innocence" (Smith, 1912:70); met ander woorde, hulle erken die oordeelsaankondiging, maar verskuif die rigpunt daarvan vanaf hulleself na iemand anders. In hierdie opsig kan ook gedink word aan die verdeling van die Israelitiese gemeenskap in regverdiges en goddeloses (Eichrodt, 1967:472). Die volk het geglo dat die oordeelsaankondigings en die oproep tot bekering gerig is net tot die sogenaamde goddeloses onder hulle en nie tot die hele volk nie. Israel het dus op die eksistensiële vertwyfeling gereageer met ontkenning en valse gerustheid. Die wisseling tussen vertwyfeling en valse gerustheid moet nie gesien word as 'n eenmalige oorgang wat op 'n sekere tyd afgehandel is nie. Dit was 'n voortdurende proses en heen-en-weer beweeg tussen die twee pole.

Dit is duidelik dat hierdie twee teenstellende pole in die profetiese boodskap problematies is en dat dit nodig is (ook vir die modeme leser) om hierdie probleem op te klaar. Die saak kom in die volgende paragraaf aan die orde.

\section{Berou en bekering in die verbond}

Die verbond wat God met Israel by Sinai 4 gesluit het, word dikwels in die lig van $\mathrm{Ou}$ Nabye Oosterse vasalverdrae geïnterpreteer. ${ }^{5}$ Dit is 'n heeltemal geldige en baie nuttige manier om die verbond te interpreteer. Daar is immers baie ooreenkomste tussen die Bybelse verbond en dié verdrae. Die Bybel het nie in isolasie ontstaan nie en God het Hom nie los van tyd en situasie geopenbaar nie. Tog is daar ook wesenlike verskille tussen die Bybelse verbond en die destydse vasalverdrae:

Die Here se verbondsverhouding is egter tog wesenlik anders as dié van vasalverdrae. Anders as die 'groot konings' het die Here hierdie mindere

4 Let daarop dat hier spesifiek na die Sinai-verbond verwys word. Die Abrahamitiese en Dawidiese verbonde verskil in 'n groter mate van hierdie vasalverdrae.

5 Vergelyk in dié verband die proefskrif van Van Rooy (1977) waarin 'n detailvergelyking gedoen word tussen die Bybelse verbond en die buite-Bybelse staatsverdrae - veral hoofstuk 8 is hier van toepassing. 
party in die verbond beslis gered. Hy het dit ook nie uit selfbelang gedoen nie, maar uit vrye genade. Hy het inderdaad hulle welsyn op die oog gehad ... (Helberg, 1980:78).

Ook wanneer die plek van berou en bekering in die verbond bespreek word, moet hierdie ooreenkomste en verskille tussen die Bybelse verbond en die vasalverdrae in gedagte gehou word.

'n Tipiese element van die vasalverdae was die seëninge en die vervloekinge (Lion-Cachet, 1990:151). Hiervolgens sou die party wat die verdrag getrou uitvoer deur die gode geseën word, maar die party wat dit verbreek, sou vervloek word. Onderhouding van die verdrag lei tot seën, en die verbreking van die verdrag tot vloek en daarmee saam die einde van die betrokke verdrag. Die verbond van God met Israel stem in 'n groot mate hiermee ooreen. Die verdrag bevat ook hierdie element van seën en vervloeking (vgl. byvoorbeeld Deut. 28). Soos 'n vasalverdrag bevat ook Deuteronomium naby aan die einde hierdie seëninge en vervloekinge. ${ }^{6}$ As die volk die bepalings van die verbond nakom, dan sal hulle deur God geseën word (Deut. 28:1-14). As hulle die bepalings oortree, sal hulle deur God gestraf word (Deut. 28:15-68). Ten opsigte van hierdie aspek stem die verbond nog ooreen met die vasalverdrae.

God se verbond met sy volk word egter nie beëindig wanneer die volk die bepalings van die verbond oortree nie: die genadige God voorsien dat die verbond voortgesit word. Die volk kan weer berou toon oor hulle sonde en hulle bekeer en dan sal Hy hulle weer seën. Hierdie aspek van die verbond word in Deuteronomium 30 verduidelik. Hier sê Moses aan die volk:

Wanneer al hierdie dinge, die seen en die straf wat ek jou voorgehou het, oor jou kom en jy daar tussen al die nasies waarheen die Here jou God jou verdryf het, daaraan dink en jy terugkom na die Here jou God en Hom gehoorsaam en jy en jou kinders met hart en siel doen wat ek jou vandag beveel het, sal die Here jou God jou omstandighede verander (Deut. 30:1$3 a)^{7}$

ó Deuteronomium word dikwels geinterpreteer as 'n verbondsdokument wat die tipiese patroon van die vasalverdrae vertoon (Lion-Cachet, 1990:137).

7 Vergelyk in hierdie opsig Van Rooy (1977:264 e.v.) wat 'n vergelyking maak tussen die struktuur van die vasalverdrae en dié van Deuteronomium. Let veral daarop dat hy die vergelyking beperk tot Deuteronomium 1 tot 28 . Die feit dat 29 en 30 uitgesluit is, dui daarop dat dit nie deel was van die vasalverdrae nie. Vergelyk dan Van Rooy (1988:865 e.v.) waar hy aantoon dat dit wel 'n integrale deel van die verbondsidee in Deuteronomium uitmaak. 
Die verloop van die verbondsgebeure kan dus soos volg voorgestel word: ${ }^{8}$

$\begin{array}{lllllll}1 & 2 & 4 & 5 & 6 & 7 \\ \text { verbond } \rightarrow \quad \text { gehoorsaamheid } \rightarrow & \text { seèn } \rightarrow & \text { sonde } \rightarrow & \text { straf } \rightarrow & \begin{array}{l}\text { berou en } \\ \text { bekering } \rightarrow\end{array}\end{array}$ seèn

Die profete se prediking gaan veral oor die verloop $4 \rightarrow 5 \rightarrow 6 \rightarrow 7$, naamlik sonde $\rightarrow$ straf $\rightarrow$ berou en bekering $\rightarrow$ seën. Die volk het gesondig en daarom is straf onafwendbaar. As hulle egter berou toon en hulle bekeer, sal God hulle weer seën.

\section{Berou en bekering in die prediking van die profete}

Die profete se prediking oor bekering en berou word tematies onder die volgende hoofde bespreek:

* Presies wat verstaan die profete onder bekering?

* Hoe verstaan hulle die verhouding tussen God se aandeel en die volk se aandeel in bekering? In hierdie deel van die bespreking word aangetoon op welke wyse hierdie prediking beter verstaan word en hoe probleme daarin opgelos kan word deur dit binne die verbondsraamwerk te lees.

\subsection{Wat beteken bekering by die profete?}

Die woord wat die meeste in die Ou Testament gebruik word om bekering aan te dui, is die werkwoord שר (Harris et al., 1980:909). In 'n omvattende studie oor die betekenis van hierdie werkwoord het Holladay (1958:53) tot die volgende basiese betekenis van die woord gekom:

... having moved in a particular direction, to move thereupon in the opposite direction, the implication being (unless there is evidence to the contrary) that one will arrive again at the initial point of departure (kursivering: Holladay).

Volgens Holladay (1958:78-81, 102-103) word hierdie woord soms in 'n verbondskonteks gebruik om bekering aan te dui (vgl. ook Jenni \& Westermann, 1976:888-889). Binne hierdie konteks beteken die woord dan die volgende: 'n radikale wegkeer van die sonde en 'n terugkeer na God, met ander woorde, die

- Hierdie gebeure moet natuuriik nie streng chronologies verstaan word nie, maar eerder siklies. Na 7 (seën) kan 4 (sonde) enige tyd weer volg sodat die siklus dan herhaal word. Dit is ook moontlik dat die gebeure by enige van punte 3,5 of 7 , d.w.s. seen, straf of seen, kan eindig. 
volk wat eens op God gerig was en toe van Hom weggekeer het, keer nou weer terug na Hom toe. Uit hierdie kort definisie van bekering volg verskeie vrae: As bekering ' $n$ terugkeer na God is, impliseer dit dat die oproep net tot die volk van God gerig word? Wat is die sonde waarvan daar weggekeer moet word? Wat beteken dit on terug te keer na God toe?

\subsubsection{Tot wie is die oproep tot bekering gerig?}

Om hierdie vraag te beantwoord is dit nodig om die verhouding tussen $\mathrm{Ou}$ en Nuwe Testament te verstaan. In die Ou Testament word God se spesifieke bemoeienis met sy uitverkore verbondsvolk beskryf. In die Nuwe Testament word die konsep van verbondsvolk uitgebrei sodat dit nie net Israel insluit nie, maar alle uitverkore gelowiges. 9 'Die Nuwe Testament vertel dus in 'n sekere sin van God se universele bemoeienis met die mensdom. Alhoewel dit 'n simplistiese weergawe van die verhouding tussen Ou en Nuwe Testament is, is dit al wat nodig is om die rigpunt van die profete se oproep tot bekering te verstaan.

Strauss (1989:86) sê dat die oproep tot bekering in die hele Bybel meestal net tot die verbondsvolk gerig word:

Weliswaar is daar die tekste (veral by Paulus) waar heidene opgeroep word om hulle te bekeer van afgode tot die diens van die regte God. Maar meestal

by die profete ... word juis die volk van God opgeroep om hulle te bekeer van hulle verkeerde wee tot die regte diens van God (my kursivering - A.W.C.)

Die oproep tot bekering van die Ou Testament in die algemeen en van die profete in die besonder is dus net tot die verbondsvolk gerig. Hierdie feit word bevestig daardeur dat Israel die onderwerp is in al die gevalle waar die Hebreeuse werkwoord שר gebruik word met die betekenis van bekering (vgl. Holladay, 1958:78-80, 102-103).

Hierdie beperkte oproep tot bekering by die profete kan verstaan word as die profete se prediking binne die raamwerk van die verbond gesien word. In die verbond is bekering 'n terugkeer tot God, 'n herstel van die verbondsverhouding. Daardie mense wat nie deel was van die verbond nie (d.i. nie

9 Vergelyk byvoorbeeld Van der Waal (1980:14) wat die verskil tussen die Ou en Nuwe Testament soos volg beskryf: "... a definite more has come into the new covenant". Een van die elemente van hierdie "more" van die Nuwe Testament is dat "the boundaries of the church have at long last been extended". 
Israeliete nie), kon hulleself per definisie nie bekeer nie. ${ }^{10}$ Eers nadat die verbondsbegrip in die Nuwe Testament uitgebrei is, kon die bekeringsoproep ook uitgebrei word. Ook binne die verloop van die verbondsgebeure wat hierbo bespreek is (vgl. 3), kom berou en bekering eers naby aan die einde van die siklus voor, waaruit logies volg dat 'n mens reeds binne die verbond moet wees om jouself te kan bekeer.

\subsubsection{Bekering is 'n wegkeer van die sonde}

As in ag geneem word dat die werkwoord 20 beteken om weg te draai van een ding na ' $n$ ander (vgl. 4.1), dan is dit duidelik dat dit in die konteks van bekering beteken om weg te draai van die sonde terug na God toe. Een aspek van bekering is dus die wegkeer van die sonde. Watter inhoud word deur die profete aan hierdie aspek van bekering gegee? In die konteks van bekering moet sonde verstaan word in terme van die gevolge daarvan (Kasdorf, 1980:39). Sonde is dus alles wat ten gevolg het dat die verhouding tussen God en die verbondsvolk verbreek word. Ook dit moet binne die verbondskonteks verstaan word:

Met die sluit van die verbond het God 'n baie persoonlike verhouding met Israel aangeknoop. Om hierdie verhouding in stand te hou is sekere bepalings gegee wat Israel moes nakom, naamlik die wet. ${ }^{11}$ In die profete se prediking oor bekering is sonde dus enige verbreking van die wet van God. God sê in Hosea 4:6b: "Omdat jy die wet van jou God vergeet het, sal Ek ook jou kinders vergeet" (1933-vertaling). (Vgl. ook Hosea 6:7.)

Uit die definisie van sonde as enige iets wat vervreemding van God veroorsaak, en dus enige oortreding van die verbondsbepalings (d.i. die wet) impliseer, volg dat sonde in die prediking van die profete 'n baie breë betekenis het.

10 Selfs in die Ou Testament was die bekeringsoproep egter nie uitsluitlik tot Israel beperk nie. Nie-Israeliete kon immers ook deel kry aan die verbond - dink aan die prostituut Ragab. Wanneer so 'n nie-Israeliet dan in die verbond ingesiuit is, kon hy/sy ook opgeroep word tot bekering. Dink in hierdie verband ook aan Jona se prediking aan die stad Ninevé.

11 In 'n studie oor die funksie van die wet in die Profete-boeke, neem Zimmerli elke profeet afsonderlik en toon aan dat alle aanklagte van die profete teen die volk op die wet gegrond is. As voorbeeld geld wat hy oor Amos sê: "Amos derives his accusations from quite explicit statements of the ancient law of God ..." (Zimmerli, 1965:68). Vergelyk ook Han (1987:13 e.v.) vir 'n interpretasie van die oordeelsprediking van die profete binne die raamwerk van wetsoortreding as verbondsverbreking. 
Aangesien die sonde waarteen die profete se oordeelsprediking gerig is reeds breedvoerig deur Westermann (1982:129-134) bespreek is, word hier net kursories daama verwys.

Die vernaamste sonde van die volk is natuurlik afgodediens, want dit is die direkte en vernaamste wyse om van God vervreem te raak. Die profete se prediking is vol van die veroordeling van afgodediens waarvan hier enkele voorbeelde genoem word: Hosea 4:12-13; Jesaja 1:29-31; Esegiël 6:5, 22:3. 'n Tweede aspek van die vervreemdende invloed van sonde wat ook direk met die mens se verhouding tot God verband hou, is vormgodsdiens. Ook hierteen het die profete gepreek (vgl. byvoorbeeld Jesaja 1:11-14; Hosea 6:1-3, 6; Amos $5: 21-25)$.

Die wet as verbondsbepalings raak ook die verhouding met die medemens; daarom lei versteurde menseverhoudinge ook tot vervreemding van God. Kasdorf (1980:40) kan sonde dus definieer as "alienation from God ... and other people" (my kursivering - A.W.C.). 'n Groot deel van die profete se prediking gaan dan oor hierdie sosiale sondes van die volk. Amos is een van die profete wat die meeste klem lê op die sosiale ongeregtigheid van die volk (Harper, 1905:xx; vgl. byvoorbeeld Amos 2:7, 8 en 5:7).

Aangesien sonde volgens die profete so omvangryk was, moes die wegkeer daarvan as deel van die bekering ook omvangryk wees. Die wegkeer van die sonde moes sowel 'n hartgrondelike terugkeer na God as 'n herstel van die verhouding met die medemens wees. "Die profete roep die volk kragtig op tot radikale verandering op alle terreine: staatkundig, maatskaplik, godsdienstig, persoonlik" (Helberg, 1980:175).

\subsubsection{Bekering is 'n terugkeer na God}

As sonde vervreemding van God is wat teweeggebring word deur die negering van die verbondsbepalings (die wet), dan behels terugkeer na God dat die wet weer nagekom moet word. God sê in Jeremia 26:3 dat Hy die oordeel van die volk sal afweer as hulle hulle bekeer, en dan word in die volgende vers verduidelik wat Hy hier onder bekering bedoel: "om in my wet te wandel wat Ek julle voorgehou het" (Jer. 26:4b - 1933-vertaling). Hierdie onderhouding van die wet moet egter nie bloot formalisties of ritualisties wees nie - dít is uitvoering van die wet sonder om na God terug te keer en Hy verwerp dit (Hos. 6:4-6).

Dit is dalk die beste om wetsonderhouding as die gevolg van die terugkeer tot God te beskou. As die volk opreg tot God teruggekeer het sodat die verbondsverhouding tussen hulle weer herstel is, sal hulle die wet om die regte redes onderhou. As hulle die wet onderhou om op hierdie wyse tot God terug te keer, 
is dit 'n nuttelose valse bekering. Onderhouding van die wet is dus die teken dat die verbondsverhouding herstel is en is nie die middel daartoe nie.

'n Vraag wat hier beantwoord moet word, is of bekering 'n terugkeer is na die verbondsverhouding presies soos dit was voor die sonde dit tydelik opgehef het. Die werkwoord שר beteken 'n terugkeer na die beginpunt (vgl. 4.1), maar impliseer dit dat die volk na hulle bekering weer in presies dieselfde verhouding met God sou staan as by Sinai? Op hierdie vraag moet sowel positief as negatief geantwoord word.

Die antwoord is positief omdat die verhouding tussen Jahweh en die volk weer dieselfde sal wees. In Jeremia 31:31-34 word die nuwe verbond tussen God en sy volk bespreek. Vroeër in die hoofstuk word eers van die berou en bekering van die volk vertel (Jer. 31:18-19). Op hierdie skuldbelydenis en bekering van die volk antwoord God vanaf vers 20 met vergewing en seën. Hierdie seën van God loop uiteindelik uit op die hoogtepunt in vers 31 waar die nuwe verbond aangekondig word. God se seënende antwoord en die nuwe verbond volg dus op die bekering. Die implikasies van die nuwe verbond word soos volg uitgespel: "Ek sal hulle God wees en hulle sal my volk wees" (Jer. 31:33b). Dieselfde gedagte kom ook na vore by die verbondsluiting by Sinai. In Eksodus 19:6 word Israel opgeroep om vir God 'n heilige nasie te wees, dit wil sê sy volk. In Eksodus 20:2 stel God Homself soos volg aan die volk bekend: "Ek is die Here jou God ...". Vergelyk ook Helberg (1990:86) wat stel dat daar nie te veel klem gelê moet word daarop dat die tenugkeer uit die ballingskap (die verlossing) die sluit van ' $n$ nuwe verbond is nie. Hierdie tenugkeer en verbondsluiting "moet eerder in dieselfde gees verstaan [word] as Eksodus 19:4-7 waarvolgens die verbond wat gesluit staan te word, tog rus op 'n wesenlike verbondsverhouding en Jahwe se verbondsoptrede" (Helberg, 1990:86). Die verbond is nie staties nie, maar dinamies. Dit is dus eerder 'n nuwe verbond in die sin van 'n aangepasde (renovated) verbond. Hieruit is dit duidelik dat die terugkeer tot God die herstel is van die verhouding soos dit lank gelede reeds bestaan het.

In ' $n$ ander $\sin$ is bekering egter nie die terugkeer na 'n identiese verhouding nie; daarom word die verbond in Jeremia 31 die nuwe verbond genoem (Jer. 31:31). Carroll (1986:611-612) verduidelik die andersheid van die nuwe verbond soos volg:

In envisaging a new $b^{e}$ rit the author of this oracle ignores the problems of the past and foresees a form of relationship between Yahweh and the nation which will avoid the defects of the old system of $b^{e} r \hat{t} t$ by virtue of internalizing the divine instructions (tôrâh). 
In die ou verbond was die wet iets ekstern aan die mens - iets wat die mens moes aanleer en dan as aangeleerde gedrag moes uitvoer. ${ }^{12}$ Dit het verskeie probleme veroorsaak, waaronder die formalistiese uitvoer van die wet, of die totale negering daarvan. In die nuwe verbond word hierdie probleme voorkom deur die wet ' $n$ integrale deel van die mens te maak - deur dit op sy hart te graveer. Nou is onderhouding van die wet noodwendig 'n saak van die hart en die mens hoef die wet nie te leer nie - dit is immers deel van hom.

Bekering as die terugkeer na die ou verhouding met God is nie repristinasie nie. Alle verandering word nie genegeer nie. Nee, bekering is 'n proses van reformasie. Die verbond is dus dinamies en het, hoewel dit in wese dieselfde gebly het, ook ontwikkel.

\subsection{Die aandeel van God en van die volk in bekering}

Eichrodt (1967:465) noem die afdeling van sy boek wat oor bekering handel (en waarin hy besonderlik na die profete verwys) "the preconditions of forgiveness". Hieruit volg 'n belangrike vraag: Is bekering volgens die profete 'n absolute voorvereiste vir verlossing? Hoe hierdie vraag beantwoord word en die motivering daarvoor het ingrypende dogmatiese implikasies. 'n Positiewe antwoord op hierdie vraag kan die idee skep dat die mens sy verlossing moet verdien, of ten minste dat hy sinergisties saam met God aan sy verlossing moet werk. Die moeilike vraag van die Goddelike vrymagtige genade en die menslike verantwoordelikheid word dus hierdeur geraak.

In hierdie deel van die artikel word die profete se prediking oor die aandeel van die mens en van God in bekering (en dus in vergewing) onder die volgende twee punte bespreek:

12 Op die oog af spreek gedeeltes soos Deuteronomium 6:4-9 teen hierdie stelling. By nadere ondersoek blyk dit dat dit eerder die stelling bevestig. In Deuteronomium 6:6 word die perfektum van die היד met die waw-konsekutief gebruik as voortsetting van die imperatief aan die begin van vers 4 . Dit is dus 'n bevel dat die wet in die mens se hart moet wees, want dit is nie outomaties daar nie. Hierteenoor word in Jesaja 31:33 die perfektum van die werkwoord נתן gebruik sonder die waw-konsekutief (of volgens tekskritiek wel daarmee, maar dan as voorsetting van die voorafgaande imperfektum), en word dus 'n stelling gemaak. In Jeremia gee God dus die verbond in die mens se hart en is dit outomaties iets intern aan die mens. Vergelyk ook hoedat daar in Deuteronomium opdrag gegee word dat die wette van die verbond aan die kinders geleer moet word (6:7), terwyl dit in Jeremia duidelik gestel word dat dit nie meer nodig sal wees dat die verbond geleer moet word nie (31:34). 
* Die wyse waarop die volk die aandeel van die mens in bekering verstaan het.

* Wat die profete bedoel het met die verhouding tussen God se aandeel en die mens se aandeel.

\subsubsection{Die volk se interpretasie}

Dat die mens 'n groot rol speel in die bekering blyk daaruit dat bekering op minstens vier-en-sewentig plekke in die Ou Testament as die roeping van die mens aangedui word, terwyl daar net op ongeveer vyf plekke gesê word dat bekering van God uitgaan (Feenstra, 1972:200). Dit blyk ook daaruit dat die werkwoord שר volgens Holladay (1958:102-103) nie in die hip' 'il gebruik word met die betekenis dat God die volk bekeer nie, maar net dat Hy hulle weer aanvaar na hulle bekering. Ook die profete se prediking self dui op die groot belang van die volk se aandeel in bekering. Amos sê byvoorbeeld: "Julle moet haat wat verkeerd is, julle moet liefhê wat goed is, julle moet opkom vir die reg in die howe [d.i. julle moet julle bekeer - A.W.C.]. Dan sal die Here die almagtige God Hom dalk ontferm oor wat daar van Josef oor is" (Amos 5:15).

Bogenoemde aanhaling laat dit lyk asof bekering 'n voorvereiste is vir vergewing, en aangesien die mens so 'n groot rol speel in bekering, asof die mens sy verlossing daardeur moet verdien. Dit is ook inderdaad die wyse waarop Israel soms die profete se prediking oor bekering verstaan het. As gevolg van die klem wat die profete op wetsonderhouding as deel van bekering gelê het (vgl. 4.1.2 en 4.1.3), het die idee by Israel ontstaan dat hulle bloot die wet hoef te onderhou om gered te word. Hulle het begin om geregtigheid aan wetsonderhouding te meet (Eichrodt, 1967:471). Israel het dan ook inderdaad by geleentheid op die profeet se oproep tot bekering gereageer deur te begin om die wet formalisties te onderhou. Hulle het geglo dat hulle sodoende vergiffenis van God sou kon verdien (Hosea 6:1-2). Israel was so seker dat hulle 'bekering' God se guns noodwendig sou maak. God aanvaar dit egter nie - Hy verwerp hierdie wettiese bekering as vals en nie wat Hy werklik verwag nie (Hosea 6:4-6). Israel kan hulle eie vergiffenis nie verdien deur wetsonderhouding nie. Ook die verdeling van die Israelitiese gemeenskap in die twee groepe van regverdiges en goddeloses het bygedra tot die idee dat bekering van die mens kom en dat die mens daardeur sy vergiffenis verdien. ${ }^{13}$

13 Vergelyk 2 hierbo vir 'n bespreking van hoe hierdie verdeling van die gemeenskap die volk se verstaan van die bekeringsoproep beperk het en hoe hierdie beperkte verstaan realiseer in die volk se houding in Maleagi 3:7. 
Die volk, wanneer hulle enigsins na die profete se prediking oor bekering geluister het, het dit dus soos volg verstaan: (i) dat bekering van hulle kant af kom en (ii) dat hulle daardeur vergiffenis verdien. Die volk se verkeerde interpretasie van wat bekering behels, is gegrond in hulle verkeerde verstaan van wat die verbond behels. Vir 'n weergawe van hierdie verkeerde verbondsinterpretasie van die volk kan die bespreking van die volk se interpretasie van die profetiese paradoks hierbo vergelyk word (vgl. 2). Omdat die volk nie die oordeelsprediking reg verstaan het nie, kon hulle ook nie die bekeringsoproep reg verstaan nie.

\subsubsection{Die profete se bedoeling}

Soos wat vroeër reeds verduidelik is, het die volk verkies om net gedeeltes van die profetiese prediking te aanvaar - die ander gedeeltes het hulle as't ware glad nie eens gehoor nie (vgl. 1.1; vgl. ook Helberg, 1992:246). Dit geld ook van die profete se prediking oor die aandeel van God en van die mens in die bekering. Die volk het verkies on net die gedeeltes te hoor wat oor die mens se aandeel handel en daardeur het hulle tot die gevolgtrekking gekom dat bekering alleen van die mens se wetsonderhouding afhang. $\mathrm{Om}$ in te sien dat bogenoemide ' $n$ verdraaide siening is, is dit nodig om weer kortliks terug te verwys na wat bekering is. Bekering is ' $n$ radikale omkeer wat 'n wegkeer van die sonde en 'n terugkeer na God behels en hierdie omkeer is nie net 'n uiterlike verandering nie, maar 'n wesenlike hartsverandering (vgl. 4.1).

Die volk het gedink dat hulleself hulle eie bekering moet en kan bewerk (vgl. 4.2.1). Hulle het dit ook by geleentheid probeer doen (vgl. Hosea 6). In sekere opsigte kon hulle hulleself bekeer - hulle kon die kultiese wette uitvoer. Hulle kon egter nie die hartsverandering (wat eintlik is wat God wou gehad het) bewerkstellig nie: "want Ek verwag liefde eerder as offers, toewyding eerder as brandoffers" (Hosea 6:6). Nog baie voorbeelde kom in die Profete-boeke voor waar God Israel se onderhouding van die kultiese wette veroordeel omdat dit nie deur ware hartsgodsdiens vergesel word nie (bv. Jes. 1:11-15; Amos 4:4-5; Miga 6:6-8). Die volk kon dus die wette formalisties nakom, maar hulle kon nie self 'n hartsverandering bewerkstellig nie, want hulle hart was "bedrieglik" en "ongeneeslik" (Jer. 17:9). Helberg (1990:103-104) beklemtoon ook dat by die profete en by Esegiël en Jeremia daar geen menslike gronde was vir die terugkeer uit ballingskap (d.i. die vergewing) nie. Hierdie vergewing vind nie plaas op grond van die volk se optrede (asof hulle die verbond gehoorsaam het nie), en ook nie ter wille van die mense (omdat hulle so swaar gekry het nie), 
maar slegs op grond van Jahwe se vrymag en ontferming oor sy volk. Die volk verdien dus nie die verlossing nie. ${ }^{14}$

As die mens homself dan nie kan bekeer nie, waarom plaas die profete soveel nadruk op hulle oproep tot die volk om hulle te bekeer? Hierop kan twee antwoorde gegee word: Ten eerste moet die volk besef dat hulle wel 'n verantwoordelikheid het. Tweedens moet hulle besef dat hulle hulle nie self kan bekeer nie en dat hulle dus nie hulle verlossing kan verdien nie.

Dit is op hierdie punt waar God inkom in die bekeringsproses. Die volk kan nie hulle eie hart vernuwe nie, en daarom gee God aan hulle 'n nuwe hart (vgl. Eseg. 36:26 Jer. 24:7; 31:31-33) - dit is op die ou end God wat die bekering bewerk en so weer die verbondsverhouding tussen Hom en die volk herstel. Vergelyk wat Helberg (1992:251) in die verband sê:

Hy [sal] 'n innerlike verandering in hulle bewerk, 'n hartsverandering, sodat hulle sy bepahings en voorskrifte sal nakom (Eseg. 36:26.27). Dan sal hulle weer in 'n verbondsverhouding met Hom staan ('... julle sal my volk wees en Ek sal julle God wees'; Eseg. 36:28).

Bekering is dus ook suiwer genade van God af - die mens kan dit nie self doen nie en daarom kan hy die redding wat daarop volg nie verdien nie. Die profete se oproep tot bekering moet dus ook gesien word in die lig van God se genadige wil om te vergewe. In hierdie verband sê Von Rad (1965:217) van Jeremia se

14 Helberg (1990:103-104) stel hier ook dat die verlossing nie op die verbond gebaseer is nie en motiveer dan hierdie stelling deur te beweer dat Jeremia en Esegiël nie een maal die verbond met Abraham as rede aanhaal wanneer die terugkeer aangekondig word nie. Hierdie verbond word wel nooit direk genoem nie, maar verwysings daama (soms baie direk) is volop. Ook heelwat verwysings na die Sinai-verbond kom voor: (i) Daar word dikwels verwys na die land wat Jahweh aan die voorvaders gegee het (Jer. 16:15; 30:3; 32:22; Eseg. 37:25). (ii) Die verbondsformule "Ek sal vir julle 'n God wees en julle sal vir My 'n volk wees" kom dikwels voor in een of ander vorm (Jer. 30:22; 31:1; 32:38; Eseg. 36:28; 37:23). (iii) In Jeremia 33:19-26 word die Dawidiese verbond sterk verbind aan die terugkeer en die verlossing. Elders (in dieselfde boek) beweer Helberg (1990:85) dat die profete soms met rede nie direkte verwysings na die verbond maak nie, maar eerder net verbondsuitdrukkings gebruik of implisiete verwysings daama maak. Hier verwys hyself dan ook na Jeremia en Esegıel as voorbeelde. In hierdie selfde konteks sê hy dan: "Tog vorm die verbond ... 'n grond of aansluitmg vir sy [Jahwe se] reddende optrede." Eintlik erken Helberg dus dat ook by Esegiël en Jeremia die verbond 'n tema is in dié profete se prediking oor verlossing, al is dit deur indirekte sinspelings. 
prediking: "His appeals to return increasingly emanate from God's decision to save."

As bekering dan geheel en al van God af kom, waar pas die mens in? "Forgiveness cannot be thought of as God's personal dealing with men for the restoration of fellowship unless Man is personally committed to this action on the part of his God" (Eichrodt, 1967:465). God is dus die party wat die bekering bewerk, maar op so 'n manier dat die verantwoordelikheid nie van Israel weggeneem word nie (Helberg, 1992:251). God eis dat Israel die wet moet onderhou as teken van hulle bekering soos dit blyk uit die volgende woorde van God in Esegiël: "Ek sal julle 'n nuwe hart en 'n nuwe gees gee ... Ek sal my Gees in julle gee en Ek sal maak dat julle volgens my voorskrifte leef en my bepalings gehoorsaam en nakom" (Eseg. 36:26-27; my kursivering A.W.C.). Nadat God die nuwe hart gegee het, volg dat die volk sy wet moet onderhou en daarvolgens moet leef.

Die verantwoordelikheid van die volk is dus om God se bekering te aanvaar en daama van harte volgens sy wet te wil leef. As die mens hierdie bekering aanvaar, is dit egter steeds nie uit sy eie verdienste nie, maar omdat God sy Gees in die mens se hart gegee het (Eseg. 36:27). God kom immers na die volk toe en nie hulle na Hom toe nie (Morris, 1981:44). God stuur immers boodskappers (die profete) na die volk toe om hulle te waarsku en aan te moedig tot bekering (Morris, 1981:45-46), God het immers die volk lief en wil hulle tot bekering bring en hulle vergewe (Morris, 1981:47-52). God doen van sy kant af alles, en as die volk dit nie aanvaar nie is dit hulle eie skuld dat hulle verlore gaan.

Hoe pas dit alles dan binne die raamwerk van die verbond? Die verbond is monopleuries in sy ontstaan, maar dupleuries in sy bestaan (Strauss, 1989:84). Dit beteken dat God alleen verantwoordelik was vir die ontstaan van die verbond. Dit was nie omdat Israel die grootste en magtigste volk was dat God sy verbond met hulle opgerig het nie. Dit het onverdiend en alleen van God se kant gekom. Net so kom bekering onverdiend en alleen van God af. Met die verbondsluiting by Sinai het God die verbond met Israel opgerig. Met bekering herstel God weer die verbond wat deur die mens verbreek is. Bekering is dus ook die monopleuriese beginpunt in die nuwe verbond.

Alhoewel God alleen verantwoordelik was vir die oprig van die verbond, stel Hy ook eise aan die volk wat die onderhouding van die verbond behels - in die onderhouding is dus sowel God as die volk betrokke (vgl. Helberg, 1980:51-52). Ten opsigte van die onderhouding van die verbond kom die mens se verantwoordelikheid in die bekeringsproses ter sprake. Nadat God die verbond 
deur middel van bekering vernuwe het, moet die volk hulle deel weer nakom. Hulle moet nou weer die eise van die verbond, die wet, gehoorsaam.

\section{Gevolgtrekking: die profetiese paradoks en bekering}

In die artikel is aangetoon dat interpretasie van die Bybel binne breë openbaringslyne wel baie kan help in die verstaan van die openbaring. Verder is ook aangetoon dat die verbond as een van hierdie sentrale lyne wel met vrug gebruik kan word. Al kan daar moontlik teoretiese besware ingebring word teen die gebruik van die verbond as sentrale tema (al staan die besware geensins vas nie - vgl. 1.2), moet erken word dat dit ten minste groot praktiese waarde het. Die verbond moet egter nie gesien word as die enigste van die groot openbaringslyne in die Ou Testament nie. Daar is ook ander openbaringslyne, soos God se koninkryk en die verhouding tussen God en skepping wat weer ander aspekte van die openbaring (ook in die Profete-boeke) kan help ontsluit.

In hierdie artikel is spesifiek aangetoon hoe die verbond as sentrale openbaringslyn kan help om die profete se prediking te ontsluit. In die profete se prediking vorm oordeel en verlossing twee van die belangrikste temas, maar staan tog ook teenoor mekaar. Hierdie teenoormekaarstelling van oordeel en verlossing veroorsaak probleme by die interpretasie van die Profete-boeke - vir die Israeliete tot wie die boodskap aanvanklik gerig was, maar ook vir die modeme leser. In hierdie artikel is aangetoon dat as die profete se prediking binne die raamwerk van die verbond gelees word, hierdie spanning tussen oordeel en verlossing opgehef word. Die profete preek dat God uit vrye inisiatief met die volk 'n verbond gesluit het op grond waarvan Hy hulle geseën het. Hulle het egter die verbond verbreek en daarom moes hulle oordeel verwag. Binne die verbondsraamwerk het God egter nuimte geskep vir berou en bekering. Hy roep ook deur die profete die volk gedurig daartoe op en $\mathrm{Hy}$ gee aan die volk deur die nuwe verbond die vermoë om berou te toon en hulle te bekeer. As hulle dan berou het en hulle bekeer, sal hulle weer sy seën ontvang. Binne ' $n$ verbondsraamwerk word die twee pole dus deur berou en bekering verbind. Aangesien berou en bekering so 'n belangrike plek beklee in die profetiese prediking (dit verbind twee van die hooftemas) is dit verder in meer detail bespreek. In hierdie opsig is aangetoon dat die verbondsraamwerk ook verder kan help om die profetiese prediking oor hierdie onderwerp te verstaan baie van die oënskynlik vreemde elemente van die profetiese prediking kan verstaan word as dit binne die verbondsraamwerk geplaas word.

\section{Bibliografie}

BRIGHT, J. 1976. Covenant and Promise: The Prophetic Understanding of the Future in Pre-exilic Israel. Philadelphia : Westminster. 
CARROLL, R.P. 1986. Jeremiah: a Commentary. Philadelphia, Pa. : Westminster. (The Old Testament Library.)

COETZEE, J.C., DE KLERK, B.J. \& FLOOR, L. 1980. Die hermeneuse van die Skrif met die oog op hedendaagse kerklik-etiese vraagstukke. In die Skriflig, 14(54):12-26.

COPELAND, P.E. 1984. A Guide to the Study of the Prophets. Themelios, 10(1):4-9.

EICHRODT, W. 1967. Theology of the Old Testament. Volume II. Translated by John Baker. London : SCM.

FEENSTRA, J.G. 1972. Leer en lewe: eenvoudige geloofsleer-leesboek. In Afrikaans vertaal deur dr. M.T.S. Zeeman. Pretoria : Sacum.

HAN, J.G. 1987. The Restoration of Israel in Covenant Perspective. An Exegetical and Revelation-Historical Study of the Prophecies of the Promise. Potchefstroom : PU for CHE. (Th.D. Thesis.)

HARPER, W.R. 1905. A Critical and Exegetical Commentary on Amos and Hosea. Edinburgh : Clark. (The international critical commentary on the Holy Scriptures of the Old and New Testaments.)

HARRIS, R.L., ARCHER, G.L. \& WALTKE, B.K. 1980. Theological Wordbook of the Old Testament. Volumes 1 and 2. Chicago : Moody.

HASEL, G.F. 991. Old Testament Theology: Basic Issues in the Current Debate. 4th ed. Grand Rapids, Mich. : Eerdmans.

HELBERG, J.L. 1980. Die Here regeer: openbaringslyn deur die Ou Testament. Pretoria : NG Kerkboekhandel.

HELBERG, J.H. 1990. Die verbondsvolk se verhouding tot sy land. Potchefstroom : PU vir CHO. (Wetenskaplike Bydraes van die PU vir CHO. Reeks A, nr. 76.)

HELBERG, J.L. 1992. Die basis en dryfkrag van die geregtigheidseis by die Groot Profete. Koers, 57(2):241-259.

HELBERG, J.L. 1993. Openbaringsgeskiedenis van die Ou Testament: Inleiding. Potchefstroom : PU vir CHO. (Th.B.-gids 1993.)

HOLLADAY, W.L. 1958. The Root sûbh in the Old Testament. With particular reference to its usages in covenantal contexts. Leiden : Brill.

JENNI, E. \& WESTERMANN, C. 1976. Theologisches Handwörterbuch zum Alten Testament. Band II. Zürich : Theologischer Verlag.

KASDORF, H. 1980. Christian Conversion in Context. Scottdale, Pa. : Herald.

LE ROUX, J.H. 1986. Tekste met 'n profetiese perspektief. (In Deist, F. \& Vorster, W., reds. Woorde wat ver kom. Kaapstad : Tafelberg. p. 123157.) (Die literatuur van die Ou Testament, Deel 1.) 
LION-CACHET, F.N. 1989. So het dit begin: Gods boodskap in die raamwerk van die historiese boeke van die Ou Testament. Potchefstroom : PU vir CHO. (Wetenskaplike Bydraes van die PU vir CHO. Reeks C, nr. 7.)

LION-CACHET, F.N. 1990. Die eerste boeke van die ou verbond: Kanoniek van die Torah/Pentateug. Potchefstroom : PU vir CHO. (Wetenskaplike bydraes van die PU vir CHO, Reeks A, nommer 75.)

MORRIS, G.E. 1981. The Mistery and Meaning of Christian Conversion. Nashville : Discipleship Resources.

NICHOLSON, E.W. 1986. God and His People: Covenant and Theology in the Old Testament. Oxford : Clarendon.

SMITH, J.M.P. 1912. A Critical and Exegetical Commentary on the Book of Malachi. (In Mitchell, H.G., Smith, J.M.P. \& Bewer, J.A. Critical and Exegetical Commentary on Haggai, Zechariah, Malachi and Jonah. Edinburgh : Clark.) (The International Critical Ccommentary on the Holy Scriptures of the Old and New Testaments.)

STRAUSS, S.A. 1989. Verbond en bekering. Acta Theologica, 9(1):79-87.

VAN DER WAAL, C. 1980. The Continuity between the Old and New Testaments. (In New Testament Society of South Africa. Proceedings of the sixteenth meeting of the New Testament Society of South Africa held at the University of Potchefstroom for Christian Higher Education from the 1 st to the 3rd of July 1980. p. 1-20.)

VAN ROOY, H.F. 1977. 'n Vergelyking van die struktuur van die buiteBybelse staatsverdrae - met besondere aandag aan die Sefire-verdrae - met die struktuur van Deuteronomium. Potchefstroom : PU vir CHO. (Proefskrif-D.Litt.)

VAN ROOY, H.F. 1988. Verbond en vergewing: Deuteronomium 29 en 30 en die deuteronomistiese geskiedwerk. Hervormde Teologiese Studies, 44(4):864-882.

VON RAD, G. 1965. Old Testament Theology. Volume II: the Theology of Israel's Prophetic Traditions. London : SCM.

WELLHAUSEN, J. 1885. Israel. (In Wellhausen, J. Prolegomena to the History of Israel. Edinburgh : Black. p. 427-548.)

WESTERMANN, C. 1982. Elements of Old Testament Theology. Translated by Douglas W. Stott. Atlanta : John Knox.

ZIMMERLI, W. 1965. The Law and the Prophets. A Study of the Meaning of the Old Testament. Oxford : Basil Blackwell.

ZIMMERLI, W. 1977. Old Testament Theology in Outline. Translated by David E. Green. Edinburgh : Clark. 